\title{
Archiwiści, bibliotekarze i uczeni w rodowej bibliotece książąt Sanguszków
}

\section{T\\. Stowniku Pracowników Ksiqżki Polskiej czytamy, iż „Biblioteka Sanguszkowska powstała $w$ poczatkach XIX wieku dzięki inicjatywie Klementyny Sanguszkowej"!} Temu stwierdzeniu przeciwstawia się fakt, iż początki ksztattowania się biblioteki sięgają swymi korzeniami XVII wieku, a wspomniana Klementyna Sanguszkowa żyła znacznie później, bo w latach 1780-1852, kładąc wielki nacisk na dalszy rozwój, znanej już szeroko ze swych znakomitych zbiorów biblioteki i archiwum rodowego.

Za pierwszego, historycznie wiarygodnego twórcę biblioteki, uważa się Szymona Samuela Sanguszkę (zm. 1637), wojewodę witebskiego reprezentującego tzw. „kowelską linię rodu”.

Ten śmiały i niezwykle uzdolniony humanista ,[...] pan jak mqdiych ludzi tak i ksiegi kochajacy, stad biblioteke swojq domowq w różnych materyach godnemi autorami zagęścip', 2 mimo rozlicznych obowiązków znajdował czas na swe pasje, a były one zadziwiające. Bo oto żołnierz i polityk w ciszy swego pałacu oddaje się sztycharsko-malarskim pasjom. Dowodem jest choćby opisany w końcu XIX stulecia, znajdujący się już wówczas w Bibliotece Dzikowskiej Tarnowskich, egzemplarz Modlit'ilnika Francuskiego z kowelskiego zbioru Sanguszki. ${ }^{3} \mathrm{Na}$ jednej z kart tego Modlitewnika widniała genealogia Sanguszków spisana drobnym pismem, po polsku, ręką jak się zdaje samego wojewody, a także liczne notatki odręczne, rysunki, ornamentyka. Szymon Samuel na stronach tytułowych zwykł oznaczać przynależność książek do swej biblioteki napisem „Sum possesor huius libri Symeon Samuel Sanguscius IM de Kowel Kasthe/lamus] Witeb/sciensisy"."

Jak zasobną była już biblioteka i jak duże musiała na użytkownikach i znawcach robić wrażenie, świadczyć moga słowa wypowiedziane przez. księdza Andrzeja Henszela Mokrskiego w 1637 r., w mowie pogrzebovej poświęconej Sanguszce: "[...] świadkiem glębokiej nauki jego byl afckt wielki do ksigg in qua libet facultata napisanych. Znalazles's wsiqzęej Bibliotece y powaznych thumaczów, y subtelnych philosophow y wonnich

Z Badań Nad Polskimi Księgozbiorami Historycznymi.

t. 18. Warszawa 1997 
krasomówców, y wybornych polityków, y uciesznych poetów a mianowicie duchownych w drodze zbawienney przewodników".

Prawdopodobnie pierwsza biblioteka Sanguszkowska mieściła się w posiadłościach Szymona Samuela na Białorusi, Białym Kowlu i Smolanach. Wraz ze wzrostem ,potęgi” majątkowej Sanguszków a to za sprawą kolejnych trzech ożenków Pawła Karola Sanguszki, ${ }^{6}$ biblioteka domowa a nade wszystko archiwum domowe, wymagały nowego, osobnego pomieszczenia, a także i osoby, która by nad całością zbiorów sprawowała fachowa pieczę. Zaistniały więc pierwsze "małe archiwa domowe" w Zasławiu, Oziercach na Białorusi i Lewartowie, ${ }^{7}$ gromadząc oryginalne dokumenty państwowe, sumariusze, papiery rodowe odnoszące się do spraw publicznych i rodzinnych.

Pierwszym znanym archiwistą w Lubartowie był Jacek Kazimierz Ratajewicz, który obowiazki swe objął w 1726 roku, o czym świadczy list jego pisany do Pawła Karola Sanguszki z Krakowa, datowany 28 kwietnia 1726 r.: , $[. ..] \mathrm{W}$ tym mi zaś preliclitari przychodzi, ieżeli nieudolna applikacya, moia należytego kresu w powinności ushug Pańskich dosyć potrafi, kiedy prawie dopiero in limine iuris exercitii w palestrze tuteyszey stanalem. Zaczynam subsit to altissimo iudicio Domini, a ia wyznaię, zem bydź powinien zawsze y teraz piszę się cum profundissima veneratione et cultu.

Jaśnie Oświeconey Waszey Ksiażęcey Mości Pana y Dobrodzieia Mego nayunizeńszym stugq - Jacek Ratajewicz

Z Krakowa die 28 Aprilis 1726 roku".

Tytułowano Ratajewicza regentem archiwum, a także sekretarzem Jego Królewskiej Mości i sądów laski marszałkowskiej Wielkiego Księstwa Litewskiego, który Paweł Karol Sanguszko przez dhugie lata sprawował. Nie był Ratajewicz bibliotekarzem sensu stricto, lecz niewątpliwie pierwszym archiwistą zbiorów sanguszkowskich. Za jego bytności na dworze lubartowskim spisane zostały i oznaczone fascykuły, ujęte całościowo $\mathrm{w}$ sumariusze. Jego rękę znać wszędzie, na każdym fascykule i dokumencie, w aktach majątkowych i w korespondencji. ${ }^{9}$ Wiadomo też, iż spod jego pióra wyszły opracowania znane jako Exepycya, tj. bruliony listów, przywilejów, nadan. Ratajewicz pełnił swoje obowiązki „archiwariusza" nieprzerwanie od 1726 roku do śmierci Pawła Karola Sanguszki, ${ }^{10}$ czyli blisko ćwierć wieku. W testamencie Sanguszko, zalecil $i$ prosil', by Ratajewicz nie opuszczał domu jego. Wolę tę archiwista ksiażęcy spełnił, pracując na dworze lubartowskim jeszcze 
do 1767 roku, a więc nieprzerwanie z górą 41 lat, służąc pomoca, wiedzą i swym doświadczeniem wdowie po zmarłym księciu, Barbarze z Duninów Sanguszkowej i jej synom. Pod opieką Ratajewicza było nie tylko archiwum w Lubartowie, opiekę swą również roztoczył nad archiwum ordynackim Janusza Aleksandra Sanguszki w Dubnie. ${ }^{\text {"1 }}$ Barbara Sanguszkowa $\mathrm{w}$ dowód jego zasług i nienagannej pracy nadała mu niewielki folwark:

".... J.Mści Panu Ratajewiczowi i żonie jego dla onych sustencyi w Lubartowie przy archiwum rezydujacym grunt pewny, Holendrya Petrykow.ska nazwany, w kluczu lubartowskim lezacy... nadat byp'. ${ }^{2}$

Następca Ratajewicza na stanowisku archiwisty był Wincenty a Paulo Czarnecki, pierwotnie pracujacy w kancelarii, prawdopodobnie koronnej. Jego pobyt w Lubartowie datowany jest już od roku 1761. O fakcie tym świadczy list Czarneckiego pisany z Warszawy 19 marca $1761 \mathrm{r}$. do Józefa Paulina Sanguszki: „[...] ze raczyles' mi W. MM. Pan Dobrodziey ten honor wyświadczyć, iz dla pomocy Jego przy Archiwum J.O.Xiężny . Jej Mości mieścić się moge". 13

W lipcu 1774 roku miał miejsce spór między Józefem Paulinem Sarguszką a jego bratem Januszem Modestem. ${ }^{1+}$ Sanguszkowie w sprawie archiwum i prac z nim związanych wydali następujący dokument: "Poniewaz po nastapionym dziale między nami dobr wszystkich, dla zwiqzku interesów, między temi dobrami zachodzqcych, Archiw um nasze rozdzielone na części być nie może, tylko pod jedney osoby wiernhscia y cnota wyprobowaney zawiadywaniem zostawac musi, proto J.Pana Wincentego a Paulo Czarneckiego regentem tegoż Archiwuni naszego stanowimy $[\ldots]$.'.

Odtąd pozostawał Czarnecki stale w Lubartowie, pracując nad rozrastającym się archiwum, zaś w 1782 r. wdowa po Józefie Paulinie, Anna z Cetnerów Sanguszkowa, w dowód uznania zasług Czarneckiego, wydała przywilej z zapewnieniem mu dożywocia na Holendryi, w razie śmierci Ratajewiczowej. ${ }^{16}$ Czarnecki nie wszedł jednak w posiadanie wspomnianego folwarku, toteż Sanguszkowie, Hieronim i Janusz Modest dokonawszy w latach 1796-1797 podziału dóbr na rzecz swoich dzieci, wynagrodzili dhugoletnie zasługi archiwisty, o czym świadczy fragment następującego dokumentu: „[...] Nizej podpisani Hieronim Wojewoda Wolynshi i Jamusz Straznik Wielki Koronny, Xiażęla Lubartowicze SanguSzkowie [...] bracia między soba rodzeni nagradzajac zashugi J.Mci Pana Win-

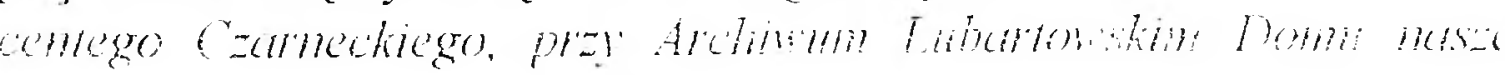


od wielu lat $z$ wiernościq dopetniane y zawdzięczajac Jego gorliwości do interessów familii naszey zawsze okazywanq kazdy $z$ nas po piętnaście tysięcy złotych polskich temuż JMci Panu Czarneckiemu zapisujemy [...]'. Dokument datowany był 15 stycznia w Zasławiu. W tymże roku, Hieronim Sanguszko, wydał dokument zapewniający Czarneckiemu dożywotnią pensję $\mathrm{z}$ dóbr Tarnowskich. ${ }^{17}$

Następcą Czarneckiego w Lubartowie został jego syn, Józef, który jeszcze za życia ojca przyuczał się u jego boku „w pracach archiwaryjnych", sporządzając samodzielnie regestrzyk papierów oddanych do archiwum w 1805 roku. 1 lutego 1809 roku podpisal Józef Czarnecki sumarjusz dokumentów, wydany miejscowemu notariuszowi Gałęzowskiemu z dopiskiem odręcznym: "Kopia ninieysza co do stowa z oryginalu ręka moiq przepisane dla informacyi w archiwum iest zostawiona - Józef Czarnecki". ${ }^{18}$

Archiwum Lubartowskie rozrosło się w przeciagu kilkudziesięciu lat do tego stopnia, iż Sanguszkowie uznali podzielić je na filie, odpowiadające podziałowi majątku z 1774 r., tak by mogły zaspokoić wymagania trzech odrębnych sched majatkowych.

W Sławucie, u Hieronima Sanguszki, Wojewody Wołyńskiego, w latach 1779-1800, archiwistą był Józef Borkowski, z siedzibą w Zasławiu, tam bowiem zgromadzone były najstarsze dokumenty dotyczace m.in. rodu Sanguszków, nadań królewskich itd. Dla dóbr tarnowskich tegoż wojewody, Hieronima Sanguszki, ustanowione zostało osobne archiwum w Tarnowie, gdzie od 1790 roku pieczę nad nim sprawował Zarębski. Niestety nie zdobył on uznania za swoją pracę u Sanguszki.

W Zasławiu, gdzie pieczę sprawował nad dobrami Janusz Modest, również istniało spore archiwum i niewielka biblioteka. Kto był tu pierwszym archiwista, nie wiadomo, zdaje się, że Borkowski, który te same obowiązki jednocześnie pełnił u księcia Hieronima w Sławucie.

$\mathrm{Na}$ Białorusi, w Smolanach i Oziercach istniało archiwum dla interesów tamtejszych dóbr sanguszkowskich już za czasów Pawła Karola Sanguszki i jego żony Barbary z Duninów, a potem od działu w 1774 roku za Józefa Paulina. Tutaj od 1796 roku obowiązki archiwisty i bibliotekarza w jednej osobie sprawował Antoni Kruszewski, a od 1814 roku Józef Czarnecki, który poza pracą stricto o charakterze dokumentalnym zajmował się interesami dóbr zasławskich i ozierskich. Był on ostatnim archiwistą $w$ dobrach białoruskich pracującym pod kierunkiem Karola Sanguszki, ${ }^{19}$ po śmierci którego dokumenty majątkowe i rodzinne zostały 
ostatecznie sprowadzone do Zasławia. Archiwa rodzinne Sanguszków, oraz pieczołowicie gromadzona biblioteka (Lubartów, Sławuta, Zasław, Smolany) rozrastały się, wymagało to zatrudnienia już nie jednej osoby na stanowisku archiwariusza i bibliotekarza, ale kilku osób ze stosownymi kwalifikacjami. Tym bardziej, że archiwum lubartowskie przez krótki czas (1809-1811), pozostawało bez fachowej opieki.

Kolejnym ,archiwariuszem”, zatrudnionym przez Hieronima Sanguszkę był Józef Bossakowski, który za zgodą Sanguszków czynił starania $\mathrm{u}$ władz rosyjskich by uzyskać zgodę na przeniesienie archiwum i biblioteki z Lubartowa, w inne miejsce. Dopiero w 1812 roku kwestia ta została ostatecznie załatwiona. Obok Bossakowskiego, majątkiem archiwalnym i biblioteką podczas przenosin z Lubartowa mieli się opiekować plenipotenci Hieronima Sanguszki: Zacheusz Woytkiewicz, Piotr Osmólski, Jakub Podolski i Stanisław Zaleski.

Osobnym dokumentem z 12 stycznia 1812 roku, Hieronim Sanguszko mianował Zacheusza Woytkiewicza archiwistą i bibliotekarzem, a także upoważnił go do przewiezienia archiwum rodzinnego $\mathrm{z}$ Lubartowa do Zasławia, dodając, iż: „[...] odnosi się to do ulożenia archiwum r(odzinnego i jego potaczenia, jako tez dalszego utrzymania porzqadku". ${ }^{20}$

W 1813 roku, już po śmierci Hieronima Sanguszki, Zacheusz Woytkiewicz złożył „przyrzeczenia wierności”, coś w rodzaju przysięgi służbowej Eustachemu Erazmowi Sanguszce, synowi zmarłego, ${ }^{21}$ następującej treści: „Ja Zacheusz Woytkiewicz, Regent Ziemski powian zastawskiego, $w$ mieyscu przysięgi na wiernośc $y$ calość powierzonego mi archiwum JOO. XX Sanguszków, nienieyszym rewersem, w ręce JO.X. Eustachego Sanguszka, Generala, dobrowolnie i rozmyślnie danym, kijrego ważność pod cięzarem sumienia, uczciwości y charakteru postanuwiam y zaręczam, iz maiąc powierzone sobie archiwum Imienia y Domm JOO. XX Sanguszków, największego bezpieczeństwa y calosici oraz porzadku strzec będę; wiadomosici o papierach znaydujacych się, prócz nalezacym do tego osobom, nikomu kommikować, a tym bardziej stanom przeciwnym wydować nie powinienem. O dokumenta do interessu potrzebne starać się mam. Informacya z dokumentów wyciagać. Sekret wszelki, iako tez na konferencyach będąc zachować, w' wynalezieniu prpierów do obrony naymocnieyszego starania przykladac, $y$ w' nich uszkodzenia naymiejyszego chronić się l...J".22

Jak długo sprawował Woytkiewicz swoją funkcję trudno dać jednoznaczną odpowiedź, z powodu braku istotnych w tej mierze dokumentć 
Wiadomo, że po 1820 roku był już generalnym pełnomocnikiem dóbr wołyńskich Eustachego Erazma ks. Sanguszki.

W latach 1829-1833 archiwistą i bibliotekarzem w Zasławiu był Józef Paczoski, który kontynuował prace rozpoczęte jeszcze przez Woytkiewicza. Paczoskiemu archiwum zasławskie Sanguszków zawdzięcza właściwe opisanie i ułożenie fascykułów oraz sprawdzenie ich wg dawnych sumarjuszów. Na listach i dokumentach, zwłaszcza ruskich, trudnych do odczytania, podawał dokładne streszczenia, które były niezwykle pomocne dla dalszych badań naukowych.

Niezwykle interesujący jest fakt, iż obowiązki i powinności archiwariusza Sanguszków określała dokładnie instrukcja, którą wydał Hieronim Sanguszko 9 sierpnia 1812 roku. Instrukcja ta była wręczona po raz pierwszy Zacheuszowi Woytkiewiczowi w Zasławiu, zawierała cały szereg powinności, jakim sprostać winien dobry archiwariusz majacy do czynienia $\mathrm{z}$ tak cennymi dokumentami: ,X. $Z$ archiwum żadnych dokumentów bez dyspozycji Xięcia JMości, lub mieysce zastępujacego, iako też z rekwizycyi podskarbiego, zawsze jednak za rewersami biorqcego wydawać a tym bardziej przeciwnym stronom, choćby do przeczytania pozwalać nie powinien" ${ }^{23}$ Oto jeden z punktów ułożonej przez Hieronima Sanguszkę instrukcji dla archiwisty zasławskiego. Szczegółowiej natomiast, choć w znacznie krótszych zdaniach, ujęta została odrębna instrukcja dla archiwum i biblioteki w dobrach białoruskich Karola Sanguszki, która wręczona była po raz pierwszy archiwariuszowi Józefowi Czarneckiemu. Zawierała ona bardzo dokładny opis czynności i powinności archiwisty i bibliotekarza a także niemniej dokładny opis dokumentów znajdujących się $w$ archiwum, za które był Czarnecki odpowiedzialny osobiście. O tym, jak bardzo zależało Sanguszkom na bogatym już archiwum domowym niech świadczy końcowa sekwencja instrukcji sporządzona przez Karola Sanguszkę: „Względem utrzymywania Archiwum $z$ ostrożnościq od ognia, w ochronieniu od zgnilizny, robactwa i myszów itd. oraz względem pośpiechu w robocie, szczególnych nie daje zleceń, spodziewajac się, ze JPan Czarnecki dopetni to wszystko z akuratnościa, pilnościq, aplikacyq i charakterem, w którym polozylem moie zaufanie, oddajac mu sklad tak wazny. Dziako sie to w Zastowin dnia... Lutego 1818 roku. K. X. Sanguszko". 24

$\mathrm{Na}$ okres prawie 9 lat zostały poważnie zahamowane prace w archiwum i bibliotece Sanguszków, spowodowane to zostało m.in. faktem, iż starszy syn Eustachego Erazma - Roman Sanguszko ${ }^{25}$ w 1829 roku 
włączył się do niepodległościowego ruchu powstańczego. Fakt ten spowodował poważne zagrożenie dla majątku Sanguszków, znajdującego się na Wołyniu a $z$ czasem odcisnął się tragicznie na losach samego Romana. ${ }^{26}$ Biblioteką opiekowała się wówczas $\mathrm{z}$ wielką pieczołowitością Klementyna z Czartoryskich Sanguszkowa, matka Romana, która z wielkim oddaniem i znawstwem porządkowała papiery rodowe oraz stare, cenne księgi. Czasowo tylko i właściwie dla potrzeb interesów prawnych „zawiadywał archiwum” Jan Szumiński.

W 1844 roku, po powrocie $z$ zesłania za udział w Powstaniu Listopadowym, wrócił do Sławuty schorowany Roman Sanguszko, który mimo postępującej głuchoty i wycieńczenia przystapił do organizowania prac wokół archiwum i biblioteki. Dzięki wstawiennictwu Michała Grabowskiego, w dniu 1 marca 1843 roku, zatrudnit on na stanowisku archiwariusza sławuckiego, Jana Krechowieckiego, który posiadał ,[...] jak $n a$ owe czasy, dosyć warunków na jego stanowisku wymaganych" ${ }^{27}$ Owocem jego pracy były dokładnie spisane sumariusze, a także, bodajże po raz pierwszy przeprowadzona próba udowodnienia początków rodu Sanguszków. Ustępując w 1848 roku ze swego stanowiska, oddał Krechowiecki swemu następcy Władysławowi Szumińskiemu uporządkowane archiwum wedle swego systemu z następującym tytułem: Opisanie Archiwum Zastawskiego JO XX Sanguszków uporzqdkowanego wedle nowego planu przy zadaniu onego w zarzqd W-u Wtadyslawowi Szumińskiemu na dniu I-go Maja $1848{ }^{28}$

Archiwum Sanguszkowskie umieszczone wówczas w Zasławiu składało się z 3 oddzielnych części:

1. głównego archiwum przywiezionego $z$ Lubartowa,

2. Białoruskiego, przywiezionego ze Smolan,

3. Zasławskiego, pałacowego, przy młodszej linii domu XX Sanguszków.

Następca Krechowieckiego, Władysław Szumiński, niewiele poświęcał czasu sprawom archiwum i biblioteki, świadczyłby o tym fakt, iż w 1864 Roman „Sybirak” Sanguszko nadmienia, iż po ,[... [ ustapieniu Krechowieckiego archiwum bylo przez 15 lat opuszczonem $i w$ zaniedbaniu". ${ }^{29}$

W 1851 roku specjalna komisja zajmująca się opisaniem Kijowskiego Okręgu Naukowego zwróciła się do księcia $z$ prośbą o współudział $w$ jego pracach $z$ zapewnieniem możliwości korzystania $z$ unikatowych dokumentów historycznych XVI i XVII wieku, które znajdowały się w archiwum rodzinnym Sanguszków. 
W oparciu o unikalne dokumenty archiwalne historyk Michał Jezierski przystapił do prac wydawniczych, pisząc m.in. te znamienne słowa: „[...] Uzbierany przez W.Ks.Mość bogaty księgozbiór, wszelkie skarby, lezace w jego archiwum, mogqce rzucić światło na nasze dzieje, sklonity go do uporzadkowania tych drogich narodowych pamiqtek $i$ natchnęty prawdziwie obywatelskq myślq wydania ich na widok publiczny" ${ }^{30}$ Michał Jezierski złożył Sanguszce dokładny plan dotyczący opublikowania dokumentów historycznych, ze szczególnym uwzględnieniem tych, które tyczą rodu sanguszkowskiego, jego wpływów na istotne wydarzenia polityczne, licznych darowizn, przywilejów, nadań. Co zaś się tyczy biblioteki, w swym liście z 19 novembra 1852 Jezierski pisał do Romana Sanguszki, iż jeśli: „[...] prócz takowego mego zajęcia [...] zechce mi. W.K.Mość powierzyć nadzór nad biblioteka, z najmilszq chęciq przyjmę ten obowiqzek [...]". $]^{31}$

Mimo podeszłego wieku i słabnącego zdrowia, Roman Sanguszko z wielkim oddaniem i znawstwem niemałym opiekował się osobiście biblioteką $\mathrm{i}$ archiwum rodowym.

W 1861 roku bratanek księcia, Roman Damian Sanguszko, objął w posiadanie połowę dóbr wołyńskich Sanguszków, tj. Księstwo Zasławskie, Sławutę i Klimówkę, gospodarując na tych rozległych dobrach wraz ze swym stryjem Romanem „Sybirakiem” Sanguszka.

Teraz obaj zajęli się losami biblioteki i archiwum, tym bardziej, że w trybie pilnym archiwum musiało zostać przeniesione z Zasławia do Sławuty. Zostało ono umieszczone w pokojach pałacu saławuckiego na drugim piętrze, jednakże $z$ uwagi na spore zagrożenie pożarowe, dokumenty ostatecznie znalazły swoje miejsce (od 1869 roku) w oficynie pałacowej.

Po przeniesieniu archiwum do Sławuty posadę archiwisty i bibliotekarza objął Leon Bożawola-Romanowski. Był to człowiek o ogromnym doświadczeniu i wiedzy. W latach 1827-1830 był już archiwistą sądu ziemskiego w powiacie latyczowskim, później adwokatem w Kamieńcu Podolskim, zaś w latach 1846-1850 naczelnikiem Zarządu Głównego Dóbr Sławuckich.

Bożawola-Romanowski pozostawił po sobie kilka całkiem udanych prac oraz liczne rękopisy genealogiczne. Ogłosił m.in. drukiem w Warszawie w 1882 roku Rodowód Hr. Pilawitów Potockich, a także przymierzał się do ogłoszenia drukiem pracy historycznej w całości poświęconej genezie rodu Sanguszkowskiego. Pracowal w archiwum i bibliotece sła- 
wuckiej do roku 1881. W następnym 1882 roku pracę tę przerwała jego śmierć. Odszedł do historii wraz ze swym chlebodawcą i przyjacielem księciem Romanem „Sybirakiem” prawie w jednym czasie.

W 1881 roku wspaniałe Archiwum i Biblioteka Sławucka przeszło na wyłączną własność bratanka zmarłego księcia, Romana Damiana Sanguszkę, ${ }^{32}$ syna Władysława. Przedsięwzięciem, które utrwaliło pamięć o Romanie Sanguszce jako człowieku świattym, a zarazem uczyniło zeń wielkiego miłośnika historii i bibliofilstwa, było zatrudnienie $\mathrm{w}$ archiwum Sławuckim Bronisława Gorczaka, ${ }^{33}$ wybitnego specjalisty i fachowca oraz zainicjowanie przez Sanguszkę monumentalnych wydawnictw historycznych, dotyczących rodu Sanguszków i Sapiehów, w opracowaniu wspomnianego już Bronisława Gorczaka oraz Zygmunta LubyRadzymińskiego. Z pracą na tym odcinku związał się Gorczak po kres swego życia. Uporządkowawszy znajdujące się w kompletnym wówczas nieładzie zbiory sławuckie, ogłosił on drukiem Katalog Rękopisów Archiwum XX Sanguszków (Sławuta 1902), oraz Katalog pergaminów znajdujacych się $w$ Archiwum XX Sanguszków w Stawucie (Sławuta 1912), który w układzie chronologicznym obejmował 325 pozycji $z$ lat 1284-1898. Wspólnie ze znanym heraldykiem, Zygmuntem LubąRadzymińskim, zajął się wydaniem poważnego zbioru dokumentów Archiwum ksiażat Lubartowiczów-Sanguszków (Stawuta 1899). W ślad za tą praca ukazały się, wydane kosztem Romana Damiana Sanguszki Poczatki rodu XX Sanguszków (Lwów 1901), Monografia XX Sanguszków oraz innych potomków Lubarta Fedora Olgerdowicza X. Ratneńskiego. T. 3. Galaź Koszyrska (Kraków 1906)

W 1881 roku, po sporządzeniu przez Gorczaka wstępnego spisu, biblioteka sławucka liczyła ok. 6000 woluminów. Roman Damian Sanguszko sygnował swoje zbiory biblioteczne exlibrisem, była nim okragła pieczęć z napisem: „Biblioteki Romana Sanguszki”.

Trudno nie docenić żmudnej pracy Bronisława Gorczaka, która zaowocowała monumentalnymi wydawnictwami tyczącymi tak archiwum, jak i biblioteki Sanguszków. Bez wątpienia położył on największe i niekwestionowane zasługi $w$ dziele porządkowania archiwum i biblioteki, a nade wszystko w dziale licznych, dzisiaj już unikatowych opracowań naukowych. Warto tu przytoczyć słowa Jezierskiego iż: "Wdzięczność i chwala dla tych, którzy nie skapiq trudów, aby nowem wskrzeszonem swiattem dodać blasku narodowi". ".4 
Po śmierci Gorczaka wydawało się, iż trudno będzie znaleźć godnego następcę na jego miejsce w Sławucie i Gumniskach. Kogoś, kto mógłby sprostać wymaganiom i kontynuować prace na tak wysokim poziomie, jak czynił to Gorczak czy Luba-Radzymiński. Tym bardziej, że nadszedł niezwykle trudny czas niepokojów społecznych i narodowych.

Lata 1914-1918 w Europie, to okres Wielkiej Wojny Narodów, przemieszczania nieustannego wojsk, ogromnego zniszczenia i wielkiej nadziei na odzyskanie niepodległości przez Polskę. Zniszczeniu uległo w tym czasie wiele cennych, unikatowych wręcz dokumentów, pamiątek historycznych, o niewymiernej dziś już wartości, tak w bibliotece jak i archiwum sławuckim. Był to bez watpienia czarny okres w dziejach rodu Sanguszków. Zniszczeniu całkowitemu uległ pałac sławucki, zaś część cennych zbiorów wywieziona została w głąb Rosji, w tym dokumenty datowane do roku 1649 . Dopełnieniem miary tragedii był fakt, iż 2 listopada (20 października) 1917 r. na stopniach pałacu sławuckiego został zamordowany w bestialski sposób ostatni właściciel Sławuty - książę Roman Damian Sanguszko. Odeszła w ten sposób w przeszłość najstarsza z ówczesnych siedzib rodowych Sanguszków. Odeszła definitywnie, gdyż po ostatecznym ustaleniu granic między Rzeczpospolitą Polską a Związiem Radzieckim, Sławuta wraz z przyległościami znalazła się poza granicami kraju. ${ }^{35}$

Nie wszystko jednak ulegało całkowitemu zniszczeniu. Ewakuowane wcześniej ze Sławuty bogate i cenne zbiory, na mocy traktatu ryskiego, jako jedne z nielicznych odzyskano w całości. Nad przekazaniem zbiorów sanguszkowskich czuwał bezpośrednio pełnomocnik rodziny Adam Wiśniewski, który dopilnował, by wywieziona wcześniej ze Sławuty do Niżnego Nowgorodu, bogata biblioteka i archiwum wróciły do prawowitych właścicieli.

Po śmierci Bronisława Gorczaka wydawało się, iż trudno będzie znaleźć godnego następcę, tak oddanego w swej pracy na stanowisku archiwisty i bibliotekarza. Przez jakiś czas pieczę nad księgozbiorem przejęła księżna Konstancja Sanguszkowa, która wzorem innych bibliotek magnackich zamówiła dla sanguszkowskich zbiorów oryginalny exlibris. Powstał on w znanych zakładach rytowniczych Agry w Paryżu w trzech identycznych heraldycznych wersjach: herb Sanguszków - Pogoń Litewska dla trzech istniejących równolegle obok siebie rodowych bibliotek: w Gumniskach, Sławucie i Podhorcach. W tym też czasie całość zbiorów bibliotecznych oceniano na około 24000 tomów, i tak: Biblioteka Gumni- 
ska - 12 000, Podhorecka przeszło 6000 i Sławucka - również ponad 6000 woluminów. ${ }^{36}$

Po przeniesieniu do Gumnisk księgozbioru i archiwum sławuckiego około roku 1924, stała się ona najważniejszą biblioteką rodową Sanguszków, wymagająca na nowo fachowej opieki i dalszego opracowania. Całość gumniskich zbiorów, biblioteki, archiwaliów i muzealiów powierzono opiece wybitnego archeologa i historyka, Mikołaja Piotrowskiego. ${ }^{37}$

Piotrowski był człowiekiem niezwykle aktywnym na polu naukowym. Członek kilku towarzystw: Towarzystwa Archeologicznego w Petersburgu, Towarzystwa Piśmiennictwa i Polskiego Towarzystwa Heraldycznego we Lwowie, kustosz muzeów w Krewie i Petersburgu. Piotrowski był niezwykle aktywny naukowo i sercem oddany księgozbiorom gumniskim i podhoreckim, których był generalnym konserwatorem i dyrektorem. Staraniem Mikołaja Piotrowskiego zostały wydane znakomite pamiętniki Marcina Grabikowskiego, burgrabiego w Podhorcach w latach 1914$19200^{38}$

W latach 1922-1923 natomiast Mikołaj Piotrowski był członkiem delegacji w Komisji Polskiej Rewindykacyjnej i Likwidacyjnej w Moskwie. To właśnie kustosz Sanguszków, jako jeden z pierwszych wszedł w 1922 roku do krypty grobowej w Kościele św. Katarzyny w Petersburgu, by zidentyfikować prochy ostatniego monarchy Rzeczypospolitej, Stanisława Augusta i przygotować mu w Polsce godny majestatu królewskiego pochówek.

Dzięki inicjatywie i staraniom Piotrowskiego Gumniska zostały aktywnie włączone do przygotowania Zjazdu Muzeologów Polskich w Tarnowie, który odbył się $\mathrm{w}$ dniach 12-13.IV.1930 r. Piotrowski wystapił tu $z$ referatem na temat akwarel $Z$. Vogela, które znajdowały się $w$ zbiorach Sanguszków. Biblioteka i Archiwum uporządkowane staraniem Piotrowskiego, służyły wszystkim, którzy zwrócili się don z taką prośbą.

Mikołaj Piotrowski był ostatnim archiwista, bibliotekarzem i uczonym, który opiekował się z tak wielkim pietyzmem i znawstwem cennymi zbiorami starych ksiagg, map i dokumentów archiwalnych Biblioteki Sanguszków. Jego śmierć w 1931 roku w jakimś sensie zamyka ponad 200-letni okres prac wielu pokoleń archiwistów, bibliotekarzy i historyków, którzy służyli swoją wiedzą i pełnym zaangażowaniem cennym zbiorom domu Sanguszków. Prace te zaowocowały cennymi opracowaniami naukowymi, które mimo, iż Biblioteka Sanguszków jako jednolity twór już nie istnieje, są arcybogatym i ciekawym materialem do daiszych studiow naukowych 
Co się tyczy zaś Biblioteki i Archiwum rodowego, losy obu określił rok 1939, a nade wszystko nowa, powojenna rzeczywistość polityczna i społeczna po 1945 roku. Ale to już temat na osobne rozważania.

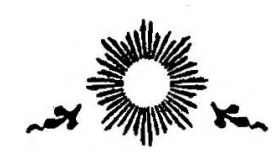

Przypisy:

${ }^{1}$ Stownik Pracowników Ksiqżki Polskiej. Warszawa-Łódź 1972, s. 787-788.

${ }^{2}$ K. Niesiecki: Herbarz Polski, T. 8. Lipsk 1830, s. 239-240.

${ }^{3}$ M. Sokołowski: Miniatury włoskie Biblioteki Jagiellońskiej i Modlitewnik francuski księcia Samuela Sanguszki w Bibliotece Dzikowskiej. Kraków 1892, s. 23.

${ }^{4}$ T.A. Żak: Szkic do historii biblioteki rodowej książ̨t Lubartowiczów Sanguszków. Tarnów 1985, s. 109.

${ }^{5}$ Tamże, s. III.

${ }^{6}$ Paweł Karol Sanguszko (ok. 1680-1750), marszałek nadworny litewski, starosta krzemieniecki i czerkaski, poślubil kolejno:

- w 1707 r. wdowę po swym bracie Bronislawę Pieniążkównę,

- w 1710 r. Mariannę Lubomirska, „z która mial syna Janusza Aleksandra sukcesora wielce niepewnego", oraz

- w 1735 r. Barbarę z Duninów. z którą mial 10 dzieci.

${ }^{7}$ Lewartów k. Lublina. dziedzictwo Firlejów, herbu Lewart. Po przejściu w ręce Pawla Karola Sanguszki ze względu na pamięc protoplasty rodu Sanguszkowskiego „zmienilo" nazwę na Lubartów. Ważna rezydencja rodowa Sanguszki, w której również obok Zasławia znajdowala siç bibliotcka.

${ }^{8}$ B. Gorczak: Katalog Rękopisów Archiw'um XX. Sanguszków w Stawucie. Slawuta : nakł. wlaściciela, druk M. Gajecki 1902.

${ }^{9}$ Tamże, s. 9.

${ }^{10}$ Pawel Karol Sanguszko zmarl w 1750 roku w Zahajcach. został pochowany w Lublinie, u oo. Kapucynów, w kościele wlasnej fundacji.

${ }^{1}$ Janusz Aleksander Sanguszko (1712-1775), ,niepcwny sukcesor”, jedyny syn Pawla Karola Sanguszki z malżeństwa z 2-ga żona Anną Marią z Lubomirskich, znany byl powszechnie ze sklonności do własnej plci. toteż ojciec za swego życia próbowal ustanowić nad jego poczynaniami kuratclę. Ratajewicz byl jednym z tych, którzy mieli pieczę nad archiwum J.A. Sanguszki. gdzie m.in. znajdowaly się ważne dokumenty archiwalne $\mathrm{z}$,transakcją kolbuszowską".

${ }^{12}$ B. Gorczak,op. cit., s. 7. 
${ }^{13}$ Józef Paulin Sanguszko (1740-1781), syn Pawla Karola Sanguszki i Barbary z Duninów, starosta krzemieniecki, rotmistrz pancerny koronny, od 1760 marszałek nadworny i od 1768 marszałek wielki litewski.

14 Janusz Modest (1749-1775), syn Pawła Karola Sanguszki i Barbary z Duninów, starosta krzemieniecki, strażnik koronny, gen. por. wojsk rosyjskich, Kawaler Orderu Orla Bialego.

${ }^{15}$ B. Gorczak, op. cit., s. 9.

${ }^{16}$ Tamże, s. 10.

${ }^{17}$ Tamże, s. 11.

${ }^{18}$ Hieronim Sanguszko (1743-1812), wojewoda wolyński, gen. pancer. wojsk rosyjskich, starosta czerkaski i kazimierski, Kawaler Orderu Orla Bialego.

${ }^{19}$ Karol Sanguszko (1779-1840), syn Janusza Modesta, Kawaler Maltański.

${ }^{20}$ B. Gorczak, op. cit., s. 17.

${ }^{21}$ Eustachy Erazm (1768-1844) - brygadier i wicekomendant kawalerii narodowej, od 1793 brygadier wojsk rosyjskich, od 1812 r. wiceregimentarz wojsk polskich, od 1817 wolyński marszalek gubernialny. Kawaler Orderu Virtuti Militari, przyjaciel księcia Józefa Poniatowskiego.

${ }^{22}$ B. Gorczak, op. cit., s. 18

${ }^{23}$ Tamże, s. 24 (pkt. 10 „Instrukcji”).

${ }^{24}$ Tamże, s. 28-29.

${ }^{25}$ Roman Adam Sanguszko (1801-1881), uczestnik powstania listopadowego 1830/31, pojmany przez oddział Kozaków w bitwie pod Łysobykami dostal się do niewoli rosyjskiej. Za udzial w powstaniu zeslany do Tobolska, później na Kaukaz. Sylwetkę księcia „kreślil piórem” J. Conrad w opowiadaniu pt. Ksiqżę Roman.

${ }^{26}$ B. Gorczak, op. cit., s. 35.

${ }^{27}$ Tamże, s. 32-33.

${ }^{28}$ Tamże, s. 32.

${ }^{29}$ Tamże, s. 33.

${ }^{30}$ Tamże, s. 35 .

${ }^{31}$ Tamże, s. 37.

${ }^{32}$ Roman Damian Sanguszko (1832-1917), syn Wladyslawa Sanguszki i Izabeli Lubomirskiej. Ostatni ordynat sławucki, znakomity gospodarz dóbr wołyńskich Sanguszków, bibliofil i milośnik sztuki. Inicjator (wraz z Gorczakiem) monumentalnych wydawnictw naukowych, opartych na materialach archiwum rodzinnego. Zamordowany w 1917 roku przez żoldaków sowieckich.

${ }^{33}$ Bronisław Gorczak (1854-1918), wybitny historyk i archiwista, urodzony we Lwowie. Od 1881-1918 zatrudniony w archiwum i bibliotece slawuckiej Sanguszków. Autor wielu prac naukowych. powstalych w oparciu o zbiory sanguszkowskie. Porzadkując zniszczone „owoce swej dlugoletniej pracy” nabawil się ciężkiej choroby pluc i zmarl w Slawucie 16.X.1918 roku.

${ }_{35}^{34}$ B. Gorczak, op. cit.. s. 38.

${ }^{35}$ W. Olasikowicz: Chłopak ze Stawutv. Warszawa 1987.

${ }^{36}$ T. A. Zak. op. cil. S. 124 
${ }^{37}$ E. Chwalewik: Zbiory polskie, archiwa i biblioteki..., Warszawa 1916, s. 30, 132, 166.

${ }^{38}$ Marcin Grabikowski z wielkim poświęceniem ratował zbiory zamku w Podhorcach przed zniszczeniem i grabieżą sowiecka w latach I wojny światowej. Rękopis pamiętnika znajduje się w Archiwum Państwowym na Wawelu. 